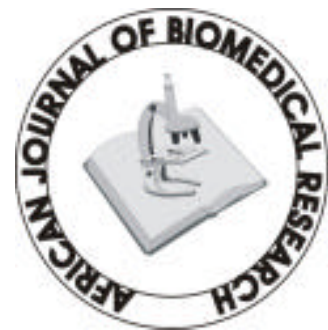

Full-text available at http://www.ajbrui.com \&

http://www.bioline. $b r / m d$

Received:

February, 2005

Accepted (Revised):

April, 2006

Published

May, 2006
Short communication

\section{Effect of Subchronic Administration of Ethanolic Stembark Extract of Mammea Africana Sabine on Haematological and Biochemical Parameters of Rats}

\author{
${ }^{1}$ Antia B. S., *2 Okokon J. E., ${ }^{3}$ Nwidu L. L. and ${ }^{2}$ Jackson C.L \\ Departments of Chemistry ${ }^{1}$ and Pharmacology/Toxicology ${ }^{2}$ \\ Faculty of Pharmacy, University of Uyo, Uyo, Nigeria \\ ${ }^{3}$ Dept. of Pharmacology and Toxicology, \\ Faculty of Pharmacy, Niger Delta University, \\ Wilberforce Island, Bayelsa State.
}

\section{ABSTRACT}

The effect of subchronic administration of ethanolic stembark extract of Mammea africana $(30-90 \mathrm{mg} / \mathrm{kg})$ on haematological and biochemical parameters of rats was studied. Significant decreases in activities of serum alkaline phosphatase (ALP), Aspartate aminotransferase (AST) and Alanine aminotransferase (ALT) as well as decreases in the levels of serum total protein and albumin were observed in the extract treated rats compared to control. White Blood Cell counts of the extract treated rats also decreased significantly while other haematogical parameters were unaffected. Thus, the extract has a slight toxicity at the doses studied. (Afr. J. Biomed. Res. 9:129 - 132 , May 2006)

Keywords : Mammea africana, alkaline phosphatase, aminotransferase, haemotology.

*Address for Correspondence: $\boldsymbol{e}$-mail: judeefiom@yahoo.com 


\section{INTRODUCTION}

Mammea africana sabine (Guttiferae) (syn. Ochrocarpus africana Oliv.) is a large forest tree of 50 to 100 feet high with bark often yellow with pale seales and resinous yellow sap (Daziel, 1956). The plant is widely distributed in tropical Africa. The stem bark of the plant is used traditionally by the Ibibios of Niger Delta region of Nigeria in the treatment of hypercholesterolemia, internal heat, and microbial infections. The chloroformic and ether stembark extract are reported to posses cytotoxic activity on cell culture (Chapuis et al., 1988). Ouahouo et al., (2004) reported cytotoxic coumarins with antimicrobial activity against Staphylococcus aureus from the plant stembark. Methanolic fractions of the stem bark have been reported to contain compounds that are potent urease inhibitor (Rahman, 2001). The stembark has been reported to contain 5,-7-dihydroxy-8-(12-methyl butryl) -4-N-Pentyl coumarins (Carpenter et al., 1971; Crichton and Waterman, 1978; Carpenter et al., 1970), Mesuxanthone B (Carpenter et al., 1971). Alkaloids have been reported to be absent in the entire plant parts. (Gartlands et al., 1980). Although reports of scientific studies on Mammea africana have been widely published, there is no information regarding the toxicity of the stembark extract in rats. Therefore this work was aimed at assessing the effect of ethanolic extract of the stembark on some hematological and biochemical parameters of rats

\section{MATERIALS AND METHODS}

\section{Plant Material}

Fresh stembark of $M$. africana was collected in November, 2004 from Anwa forest in Uruan area of Akwa Ibom State and authenticated by Dr. (Mrs) Margaret Bassey, a taxonomist in Botany Dept, University of Uyo, Uyo - Nigeria. Hebarium specimen was deposited at Faculty of Pharmacy hebarium, University of Uyo with voucher no. FPHU 381.

The fresh stembark were cut into pieces and dried on a laboratory table for 2 weeks and reduced to powder. The powder $(300 \mathrm{~g})$ was macerated in ethanol $(500 \mathrm{ml})$ for 72 hours. The liquid extract obtained was concentrated in vacuo at $40^{\circ} \mathrm{C}$. The yield was $3.51 \%$. The extract was stored in a refrigerator at $4^{0} \mathrm{C}$ until used for experiment reported in this study.

\section{Animals}

The animals used in the study were young adult male and female albino wistar rats (150-220g) and mice (22-30g) obtained from University of Uyo animal house, Uyo, Nigeria. The animals were used after acclimatization period of 10 days to room temperature and relative humidity of $28 \pm 5^{\circ} \mathrm{C}$ and $50 \%$ respectively. They were housed in standard cages and maintained on standard animal pellets and water ad libitum. The study was approved by University of Uyo College of Health Sciences Animal Ethics Committee.

\section{Acute Toxicity}

Mice were treated intraperitoneally with doses ranging from 50 to $1000 \mathrm{mg} / \mathrm{kg}$ of the crude extract. The animals were inspected for appearance of signs of toxicity for 24 hours and number of deaths was also recorded. $\mathrm{LD}_{50}$ value was calculated using the method of Lorke (1983).

\section{Subacute Toxicity}

The extract was administered by gavage to three groups of 5 animals each at 30, 60 and $90 \mathrm{mg} / \mathrm{kg}$ doses on alternate days for 21 days between 08:00 and 09:00 hour each day. Animals in control group were given normal saline $5 \mathrm{ml} / \mathrm{kg}$ orally. Twenty four hours after the last administration, the animals were anaesthesized with ether vapour and dissected. Whole blood was obtained by cardiac puncture from each rats into sample bottles. Ethylene-diaminetetraacetic Acid (EDTA) was employed as anticoagulant. Serum Aspartate aminotransferase (AST), alanine aminotransferase (ALT), alkaline phosphatase (ALP), total protein and albumin were determined using Randox test kits. Blood haemoglobin, packed cell volume (PCV), and Red blood cell (RBC) and white blood cell (WBC) counts were determined by methods of Jain (1986). Blood was diluted in 1,200 Dacie's fluid which keeps and preserves the integrity of the RBC. For white blood cell (WBC) counts the dilution factor was 1:20 using 2-3\% solution of acetic acid to which gentian violet was added.

\section{Statistical Analysis}

All data obtained were statistically analysed using students' t-test, at $\mathrm{P}<0.05$. 


\section{RESULTS}

The extract $(50-1000 \mathrm{mg} / \mathrm{kg})$ produced physical signs of toxicity 30 minutes to one hour after the administration of the extract.The signs of toxicity ranged from writhing ,decreased motor activity, gasping, decreased respiratory rate and body and limb tone to death. The intensities of all these effects were proportional to the dose administered. The intraperitoneal LD50 was calculated to be 387.3 $\mathrm{mg} / \mathrm{kg}$. Administration of ethanolic stem bark extract of Mammea africana $(30-90 \mathrm{mg} / \mathrm{kg})$ did not produce deleterious alteration in the levels of ALP, AST and ALT of the extract treated rats compared to control eventhough significant decrease in ALP and AST levels was observed. However, there was a dose dependent significant $(\mathrm{P}<0.01)$ decrease in the levels of total protein and albumin.

The administration of the extract did not produce considerable changes in the haemotological parameters of extract treated rats except a significant increase (P $<0.01)$ in WBC counts which was dose dependent.

Table 1:

Effect of Ethanolic Stembark Extract of Mammea africana On Some Biochemical Parameters AST, ALT And ALP Levels of Rats

\begin{tabular}{lccccc}
\hline $\begin{array}{l}\text { Parameters } \\
\text { Dose mg/kg }\end{array}$ & $\begin{array}{c}\text { ALP } \\
(\mathbf{I U} / \mathbf{L})\end{array}$ & $\begin{array}{c}\text { AST } \\
(\mathbf{I U} / \mathbf{L})\end{array}$ & $\begin{array}{c}\text { ALT } \\
(\mathbf{I U} / \mathbf{L})\end{array}$ & $\begin{array}{c}\text { Total Protein } \\
(\mathbf{g} / \mathbf{d l})\end{array}$ & $\begin{array}{c}\text { Albumin } \\
(\mathbf{g} / \mathbf{d l})\end{array}$ \\
\hline Control & $132.5 \pm 0.91$ & $81.5 \pm 1.85$ & $34.5 \pm 0.50$ & $66.1 \pm 0.60$ & $36.9 \pm 0.65$ \\
\hline 30 & $129 \pm 1.00$ & $73.4 \pm 2.94$ & $35.5 \pm 1.12$ & $62.0 \pm 1.28^{* *}$ & $32.1 \pm 1.30^{* *}$ \\
\hline 60 & $120.0 \pm 1.51$ & $55.5 \pm 2.77$ & $29.5 \pm 2.35$ & $55.6 \pm 1.16^{* *}$ & $30.4 \pm 1.07 * *$ \\
\hline 90 & $119.5 \pm 1.35$ & $63.0 \pm 4.00$ & $30.0 \pm 2.01$ & $56.8 \pm 1.27 * *$ & $23.1 \pm 0.9 * *$ \\
\hline $\mathrm{n}=5$ & $* * \mathrm{P}<0.01$ & & & &
\end{tabular}

Table 2:

Effect of Ethanolic Stembark Extract of Mammea Africana on Haematological Parameters of Rats

\begin{tabular}{|c|c|c|c|c|c|c|c|}
\hline $\begin{array}{l}\text { Haematological } \\
\text { parameters } \\
\text { Treatment } \\
\text { Dose mg/kg }\end{array}$ & $\operatorname{PCV}(\%)$ & $\begin{array}{c}\text { RBC X } \\
1^{6} \\
(N / \mu l)\end{array}$ & Hb (g/dl) & $\begin{array}{l}\text { MCV } \\
\left(\mu \mathbf{m}^{3}\right)\end{array}$ & $\begin{array}{c}\text { МCHC } \\
(\%)\end{array}$ & MCH (pg) & $\begin{array}{c}\text { Total WBC } \\
\times 10^{9} / 1\end{array}$ \\
\hline Control & $47.0 \pm 0.91$ & $5,3 \pm 1.17$ & $15.6 \pm 0.14$ & $8.86 \pm 1.30$ & $33.1 \pm 0.02$ & $29.4 \pm 1.03$ & $9.2 \pm 1.01$ \\
\hline 30 & $45.5 \pm 1.27$ & $5.1 \pm 1.87$ & $15.15 \pm 1.02$ & $8.92 \pm 1.08$ & $33.2 \pm 0.51$ & $29.7 \pm 1.01$ & $5.0 \pm 1.00$ \\
\hline 60 & $44.0 \pm 1.81$ & $4.9 \pm 0.89$ & $14.65 \pm 0.65$ & $8.97 \pm 0.12$ & $33.3 \pm 1.03$ & $29.9 \pm 1.13$ & $4.05 \pm 0.45$ \\
\hline 90 & $45.0 \pm 0.5$ & $5.0 \pm 1.02$ & $15.0 \pm 0.03$ & $9.0 \pm 0.21$ & $33.3 \pm 1.51$ & $30.0 \pm 0.81$ & $2.8 \pm 0.51$ \\
\hline
\end{tabular}

\section{DISCUSSION}

An investigation on the toxicity of Mammea africana stembark extract was carried out. Decreases in the levels of transaminases and alkaline phosphatase activities were observed. In this study this drop in activity is likely due to inactivating or inhibiting actions of the extract on the enzymes. It is likely that this extract may be accumulating in the liver, thus exerting its effect by reducing enzyme activities. ALT is a hepato-specific enzyme that is principally found in the cytoplasm of rats (Benjamin, 1978; Ringer and Dabieh, 1979). AST is present in high quantities in the cytoplasm and mitochondria of the liver, also in the heart, skeletal muscles, kidneys and brain (Benjamin, 1978), while alkaline phosphatase in localised in the bile duct. Increases in enzymatic activity of ALT, ALP and AST in the serum directly reflects a major permeability or cell rupture (Benjamin, 1978). The significant $(P<0.01)$ decrease in serum total protein and albumin may have resulted from the inhibitory effect of the extract on protein synthesis processes. Though there was no pronounced effect on haematological parameters except for the decrease in WBC which is likely to be due to suppression of leucocytosis in the bone marrow. In conclusion, the 
ethanolic stembark extract of Mammea africana is slightly toxic at the doses studied.

\section{Acknowledgement}

The authors are grateful to Mr. Efiong Bassey of Chemical Pathology Dept. University of Uyo Teaching Hospital, Uyo.

\section{REFERENCES}

Benjamin M. N. (1978): Outline Of Veterinary Clinical Pathology. University Press. Iowa, USA. Pp. 229-232.

Carpenter I, Mc Garry E. J. And Scheimann F. (1970): The Neoflavonoids And 4-Alkylcoumarins From Mammea Africana G. Don Tetrahedron Lett. 46: 3983-3986.

Carpenter I., Mc Garry E. J. And Scheimann F. (1971): Extractives From Guttiferae. Part XXI. The Isolation And Structure Of Nine Coumarins From The Bark Of Mammea Africana G. Don J. Chem. Soc. 22:3783-3789.

Chapius J. C.; Sordat B. And Hostettman K. (1988): Screening For Cytotoxic Activities Of Plants Used In Traditional Medicine. J. Ethnopharmacol. 2322 (2/3): 273-
284.

Crichton E. G. And Waterman P. G. (1978): Dihydromammea C/Ob: A New Coumarin From The Seed Of Mammea Africana. Phytochemistry 17: 1783-1786.

Daziel J. M. (1956): Useful Plants Of West Tropical Africa. Crown Agents For Overseas Government, London. Gartlans J. S., M. C. Key D. B., Waterman P. G., Mbi C. N. Struhsaker T. T. (1980): A. Comparative Study Of The Phytochemistry Of Two African Rain Forests. Biochem Syst. Ecol. 8:401-422.

Lorke D. (1983): A New Approach To Practical Acute Toxicity Testing. Archieves Of Toxicology.54:275 - 287.

Ouahouo B. M., Azebaze A. G., Meyer M., Bodo B. Fomum Z, T, Nkengfack A. E. (2004): Cytotoxic And Antimicrobial Coumarins From Mammea Africana. Ann. Tropical Medicine And Parasitology. 98(7): 733-739.

Rahman A. And Choudhary M. (2001): Bioactive Natural Products As A Potential Source Of New Pharmacophores A Theory Of Memory. Pure Appl. Chem. 73 (3) 555-560.

Ringer, D. H. And Dabieh L. (1979): Haematology And Clinical Biochemistry. In: The Laboratory Rats. Vol. 1 Edited By H. J. Baker, J. R. Lindsey, S. H. Weisbroth. Academic Press. London. Pp. 105-116. 